\title{
Real Convergence in the European Union. Bridging the Gap between the New and Old Member States
}

\author{
Ana-Maria Holobiuc*
}

\begin{abstract}
:
One of the fundamental pillars of the European Union aims at the convergence of economic performances among its Member States. This objective has become increasingly challenging with the advancement of the integration process from the customs union to the economic and monetary union, from the six founding Members to twenty-seven European states. The aim of this paper is to study real convergence in the European Union between 2000 and 2019 and conducting also a comparative analysis between the New and the Old Members. The methodological tools imply absolute and conditional $\beta$ - and $\sigma$-convergence. By using cross-sectional regressions, we have found evidence in favour of the absolute $\beta$-convergence hypothesis, as the initially poorer Members experienced higher GDP per capita growth rates than the developed economies. The average catching-up speed in the European Union was $2.5 \%$, while the Central and Eastern Members experienced a higher convergence rate, which reached $3.6 \%$. Moreover, by applying panel regressions, we have found evidence supporting the conditional convergence hypothesis, the study emphasising the role of macroeconomic, social, and governance-related variables in promoting economic growth. Our research suggests that investment and trade had a major role in enhancing economic growth both at the aggregate and subgroup level. Finally, the paper illustrates that $\beta$-convergence was accompanied by a reduction of disparities within the European Union. However, the global financial crisis hampered the convergence process among the Old Members. The paper suggests that although the Central and Eastern European countries made important progress in terms of catching-up, convergence of economic performance in the European Union has not been reached so far. By contrast, the modest growth rates and the exacerbation of income differentials between the Old Members might call into question the perspective to achieve this objective in the short term.
\end{abstract}

Key words: European Union; Real Convergence; Central and Eastern Europe; $\beta$ convergence; $\sigma$-convergence.

JEL classification: $\mathrm{O} 40 ; \mathrm{O} 52 ; \mathrm{O} 57$.

Ana-Maria Holobiuc, The Bucharest University of Economic Studies, 6 Piata Romana, $1^{\text {st }}$ district, Bucharest, 010374 Romania, <anamaria_holobiuc@yahoo.com>, ORCID: 0000-0001-93299758.

The research is part of the $\mathrm{PhD}$ Thesis entitled "The analysis of real convergence in the European Union. Desideratum and state of affairs" 


\section{Introduction}

Being initially established from the initiative of six countries as a customs union, the European project has rapidly advanced in terms of both enlargement and deepening, comprising nowadays twenty-seven European countries under the principles of an economic and monetary union. During its existence of seven decades, the European Union has proven its ability to unite under the same values countries with different levels of development, social characteristics and historical paths; the concept "united in diversity" becoming a leitmotif of the group with the incorporation of the Centre and Eastern countries. Although the European integration project has faced diverse and complex challenges ranging from oil, economic and financial, immigration, and sanitary crises, the European Union has proven its capacity to turn enemies into allies, political turmoil into stability and cooperation, and pauperism into prosperity.

The main purpose of this paper is to study real convergence in the European Union while also conducting a comparative analysis between the eleven New Members from Central and Eastern Europe (CEE) and the Old Members (the founding Members and the European countries that have joined the European Union before the 2000s) by taking into consideration absolute and conditional $\beta$ - and $\sigma$ convergence. The results of the absolute convergence model based on crosssectional regressions confirm the neoclassical growth model assumptions, respectively that the initially poorer Members have experienced higher GDP per capita growth rates than the developed ones. The empirical study suggests that the catching-up speed at the level of Community was around $2.5 \%$ between 2000 and 2019. Despite the favourable trends identified at the aggregate level, the subgroup analysis points at divergent results. On the one hand, the eleven New Members from CEE have experienced a higher convergence speed compared to the Community average that reached on average 3.6\%. On the other hand, we did not find robust evidence in favour of absolute $\beta$-convergence in the Old Members cluster, the results of the regression analysis indicating rather divergent trends among these economies.

In order to study the conditional $\beta$-convergence, we have employed panel regressions using generalised least squares method for the European Union and the two subgroups - the New Member States and the Old Member States. This method allows us to take into consideration the heteroscedasticity and serial correlation between errors, two vulnerabilities that are frequently present in the study of the economic growth process based on panel data. Given the complexity of the convergence process, we have tried to capture the influence of several variables that are not only related to the macroeconomic environment, but are also representative for the social and institutional framework. We have initially computed the equation taking into consideration three variables related 
to the level of investment (gross fixed capital formation as a percentage of GDP), trade (sum of exports and imports as a percentage of GDP), also including the initial level of GDP per capita. Subsequently, we have expanded the equation with other determinants aiming at the performance of the financial sector (market capitalisation of listed domestic companies as a percentage of GDP), labour market (the unemployment rate), Strategy Europe 2020 (early leavers from education and training) and governance (the rule of law - part of the Worldwide Governance Indicators). The empirical analysis confirms the conditional convergence hypothesis for the European Union and the two subgroups, taking into consideration the negative relationship between the lagged value of GDP percapita and the annual growth rates. The empirical study highlights the importance of investment, trade and a well-developed financial market in promoting economic growth. Moreover, our research confirms that the progress achieved by the Member States in terms of reducing the percentage of early leavers from education and training, as part of the Strategy Europe 2020, and strengthening the governance framework, mainly in the field of the rule of law, contributed to the catching-up process.

The paper is structured as follows. Section 2 summarises the economic growth theories and the relevant empirical studies aiming at the convergence process in the European Union, while Section 3 presents the database and the methodology used in order to test the assumptions of the paper. In Section 4, we have presented the results of the study regarding the absolute and conditional $\beta$-convergence and $\sigma$-convergence. Lastly, we have summarised the findings and proposed future directions of research.

\section{Literature review}

The advancement of the integration process was accompanied not only by large and complex challenges, but also by the expansion of the scope of convergence. Particularly, two main categories of convergence emerged from the debate of representatives of academia and practitioners. Firstly, the Maastricht Treaty (1992/1993) brought to the fore the necessity for the Member States to comply with the nominal criteria, as a prerequisite to enter the Euro Area. Despite the initial success that accompanied the launch of the euro currency, the economic and financial crisis and later the sovereign debt crisis highlighted the vulnerabilities of the criteria defined in the Maastricht Treaty. As a result, the focus of the European policy-makers has gradually shifted from nominal criteria to the real dimension of convergence. Unlike nominal criteria, which are clearly stated in the Community legislation, real convergence does not take into consideration a limited set of parameters. Although not defined in the European Union treaties, real convergence is usually referring to the efforts 
to harmonise the economic performance among the Members and to reduce income gaps between the EU countries and regions.

Since the 20th century, researchers have become increasingly interested in study of the fundaments of the catching-up process and the main determinants of economic growth. Consequently, two main theories have been developedthe neoclassical and the endogenous models. The proponents of the neoclassical growth model (Ramsey, 1928; Solow, 1956, Swan, 1956) postulated that economies with initially lower income and capital stocks experience higher growth rates than advanced economies due to the decreasing returns to capital. From the perspective of the representatives of this thought view, all economies were to reach the same state of equilibrium, where the proportion between the labour and capital was constant, while the technological factor was exogenously determined. However, given the difficulty of some of the developing economies to follow the ascending trajectory, the applicability of the neoclassical theory began to be questioned towards the end of the last century. On this occasion, new theories (called endogenous) were developed which presumed that the poorer economies would not necessarily reach the development level of the advanced economies. From this perspective, the developed economies could continue to grow, exceeding the equilibrium defined by the neoclassical model, while the low-income countries might have lagged behind. In the endogenous model, developed by Lucas (1988) and Romer (1989), the capital factor no longer includes only the physical capacities, but also the intellectual abilities of the labour factor. Moreover, in this framework, the decision-makers have no longer a passive role like in the neoclassical theories, but can stimulate the process of catching-up. Both theories may provide a better understanding of the realities that have occurred in practice, including those at the European Union level, where in recent years there have been a number of dichotomous perspectives: central versus peripheral members, single-speed versus multi-speed Europe, Eurozone versus non-euro countries, supranationalism versus intergovernmentalism.

The expansion of the integration process within the European continent was accompanied by an increase of the studies aiming at the topic of convergence. Particularly, researchers were interested to analyse the possibility to assure the convergence of economic performances in the enlarged European Union. Nowadays, the literature aiming at the topic of convergence has multiple dimensions, based on several dichotomist visions: New versus Old Members, European Union versus Eurozone, national versus regional axes, Member State versus Candidate countries. Given the scope of the paper, our analysis brings to the fore the New versus Old Member State dichotomy. Previous studies were conducted by Rapacki and Próchniak (2009), Stanišić (2012), Dobrinsky (2013), Dobrinsky and Havlik (2014), Alcidi et al. (2018), Rapacki and Próchniak (2019) 
and Stoica et al. (2019) who analysed income convergence at the aggregate level, also conducting in-depth comparisons between the New and Old Members.

Analysts generally tend to reach a consensus regarding the "iron law" of convergence (Barro, 2012) which presumes that economies will converge with a common rate of $2 \%$ per year, also illustrating that CEE group tend to experience a higher catching-up speed compared to the Community average. For example, Dobrinsky (2013) identified a convergence speed of around 2\% taking into consideration both the absolute and conditional frameworks, concluding that the Member States need 35 years to reach halfway towards equilibrium. Regarding $\sigma$-convergence, the analyst identified a downward trend in the case of the European Union (27) between 1995 and 2011. In another research, Dobrinsky and Havlik (2014) also found evidence in favour of the neoclassical growth model assumptions, the convergence speed being around $2 \%$ per year. At the same time, Dobrinsky and Havlik illustrated that the New Member States form a convergence club, given the similar economic and social characteristics and economic growth paths. Regarding $\sigma$-convergence, analysts identified a downward trend of income gaps at the Community level. Among the New Member States, the standard deviation had higher values at the end of the last century, decreasing since 2000. Vojinović et al. (2009) also illustrated that income convergence took place in the second half of the 1990s and at the beginning of the third millennium. According to Vojinović et al., the convergence speed was $4.2 \%$ between 1992 and 2006, but the highest performances were reached during the timespan 2002 and 2006, which ranged between $7.0 \%$ and $9.6 \%$. Similarly, Alcidi et al. (2018) found evidence in favour of income convergence in the CEE countries between 2000 and 2015. In contrast, Alcidi et al. illustrated that the growth rates of the Mediterranean countries were modest, this group lagging behind the rest of the Members.

Rapacki and Próchniak (2009) examined real convergence in the New Member States in relation to the European Union (15), also conducting a comprehensive analysis of the determinants of economic growth in CEE. The results of (absolute) $\beta$-convergence confirm the neoclassical growth model assumptions, as the initially poorer CEE Members experienced higher GDP per capita growth rates, the convergence speed in the EU (25) being around 2.84\% between 1996-2007. Regarding $\sigma$-convergence, the analysts pointed out that the income differences decreased during the period under review both at the aggregate and subgroup level. In another study, Rapacki and Próchniak (2019) identified a convergence rate of 2.2\% for the timespan 1995 and 2015, the winners of the convergence process being the Baltic States, which recorded annual growth rates of 4.5-5\%. In the group of former members, Luxembourg and Ireland experienced the highest growth rates. Similar to other researchers, Rapacki and Próchniak pointed out that 
the New Member States would need 30-35 years to reach halfway of the transition towards the equilibrium state. The analysis of sub-periods indicated a higher rate of convergence after the accession to the European Union (2004-2015) both at the aggregate $(2.27 \%)$ and subgroup levels $(3.44 \%)$. In terms of $\sigma$-convergence, analysts noted that the income disparities between the New and Old Members decreased during the period under review, especially after 2000.

Similarly, Stoica et al. (2019) conducted a comparative analysis between the New and Old Member States, also highlighting the impact of the economic and financial crisis on the catching-up process. Using cross-section regressions in order to study absolute convergence, analysts identified an average convergence speed of $2.63 \%$ between 1995 and 2018. The study of conditional convergence suggested that investment played a major role in generating economic growth at the aggregate level, while the inflation rate, capital flows and private lending had a negative impact. The sub-group analysis showed that the convergence rate was higher for the Old Member States under the conditional model, given the favourable influence of the macroeconomic and institutional variables. In the same line, Stanišić (2012) identified a convergence rate of $1.7 \%$ for the European Union between 1993 and 2010 under the absolute framework. The study of the conditional model revealed that the convergence process was positively influenced by the level of education and the life expectancy at birth, investment, exports and a positive public balance. In contrast, Stanišić revealed that the growth rate was inversely correlated with the fertility rate and inflation.

In conclusion, the literature background aiming at the topic of real convergence with focus on the European Union is vast and complex. The evolution that occurred in the European Union was under the magnifying glass of the researchers and decision-makers, especially after the last waves of expansion towards the Central and East of the continent. The analyses mainly take into consideration the evolution of income per capita, the comparisons between groups of countries offering some valuable insights regarding the convergence-divergence dichotomy.

\section{Research design}

The empirical study is based on the methodological framework developed by Barro and Sala-i-Martin (1990, 1992): $\beta$ - and $\sigma$-convergence. $\beta$-convergence aims at the potentially negative relationship between the initial level of income and the subsequent growth rates, while $\sigma$-convergence studies whether divergences between economies reduce over time. The concept of $\beta$-convergence is derived from the neoclassical growth model and assumes diminishing returns to capital. From this perspective, the initially poorer economies with a lower capital stock experienced higher growth rates than the developed economies 
due to the higher profitability of the production factors. From the debate of the neoclassical and endogenous models resulted two categories of convergence. The absolute $\beta$-convergence assumes that economies with similar initial development levels will tend towards "a state of balanced growth", where "the capital-labour ratio is a constant, and the capital stock expends at the same rate as the labour force" (Solow, 1956). The conditional convergence takes into consideration the potential differences between economies, which will reach in the long term different states of equilibrium. In this framework, the convergence speed will depend on the distance of each economy from its own equilibrium. In the conditional framework, the structural differences between countries are methodologically controlled by including other explanatory variables in the regression model. The study of $\beta$-convergence has been completed by $\sigma$ convergence, which studies if income differentials diminish over time. According to Barro and Sala-i-Marin (1992), " $\beta$-convergence is a necessary, but not a sufficient condition for $\sigma$-convergence". Consequently, even if the poorer economies experience higher GDP growth rates than the developed countries or regions, this might not be sufficient to reduce the income differentials between them.

With the purpose to determine conditional $\beta$-convergence, we have estimated four equations, based on panel regressions and using the generalised least squares method. The selection of the variables is a challenging step for the researchers, given the multitude of factors that influence the economic growth process. Taking into consideration the impossibility to capture in the empirical model all the catalysts, we have chosen several variables that are representative of the macroeconomic, financial, social and institutional frameworks. We have initially selected two explanatory variables aiming at the level of investment and trade openness. Then, the equation was expanded with other variables representative for the financial and labour markets, Strategy Europe 2020, and the governance framework. The dependent variable was the annual GDP percapita growth rate. The following explanatory variables included in the conditional convergence model have been extracted from the World Bank database: the gross fixed capital formation as a percentage of GDP (GFCF), the volume of trade as a percentage of GDP (Trade), the market capitalisation of listed domestic companies as a percentage of GDP (market capitalisation), the unemployment rate as a percentage of the total labour force (unemployment) and the rule of law indicator, part of the Worldwide Governance Indicators. Data aiming at the GDP per capita and the percentage of early leavers from education and training was extracted from the Eurostat database.

The indicator $\sigma$-convergence has been estimated based on time-series data taking into consideration the timespan 2000-2019. We have initially presented 
the evolution of $\sigma$-convergence computed on the coefficient of variation using graphical representation, subsequently followed by the performed regression analysis.

We have computed absolute and conditional $\beta$ - and $\sigma$-convergence for the European Union and two subgroups of countries - the New Member States, which comprises Bulgaria, Czech Republic, Croatia, Estonia, Hungary, Latvia, Lithuania, Poland, Romania, Slovakia and Slovenia, and the group of Old Member States, which includes Austria, Belgium, Denmark, Finland, France, Germany, Greece, Italy, Ireland, Luxembourg, Netherlands, Portugal, Spain, Sweden and the United Kingdom. We have excluded from the analysis of conditional $\beta$ convergence Cyprus, Luxembourg and Malta given the large offshore activities that might have biased our analysis.

In order to test (absolute) $\beta$-convergence, we have employed simple crosssectional regressions, where the independent variable is the logarithm of GDP per capita in 2000 and the dependent variable the average growth rate between 2000 and 2019:

$$
\frac{1}{T} \ln \left[\frac{y_{i, t}}{y_{i, 0}}\right]=a+a_{1} \ln \left(y_{i, 0}\right)+u_{i}
$$

$y_{i t}=$ GDP per capita of economy " $i$ ” in 2019

$y_{i 0}=$ GDP per capita of economy " $\mathrm{i}$ " in 2000

$\mathrm{T}=$ number of years

$\alpha=$ constant

$\mathrm{u}=$ error term

The speed of convergence was computed as follows:

$$
\beta=-\frac{1}{T} \ln \left(1+\alpha_{1} T\right)
$$

The number of years which are necessary in order to reach halfway towards the state of equilibrium was determined based on the formula:

$$
t^{*}=\frac{\ln 0.5}{\beta}
$$

In order to study conditional $\beta$-convergence, we have employed panel regressions taking into consideration several economic and social variables. We have used 
the generalised least squares and the regressions were performed with robust standard errors. All the equations included as the explanatory variable the lagged value of GDP per capita. We have initially studied the impact of two variables related to investment and trade, based on the following equation:

$\ln \left(\Delta y_{i, t}\right)=a+\beta_{1} \ln \left(y_{i, t-1}\right)+\beta_{2} \ln \left(G F C F_{i, t}\right)+\beta_{3} \ln \left(\operatorname{Trade}_{i, t}\right)+u_{i, t}$

Then, we have expanded Equation 1 by including one variable related to the financial sector - the market capitalisation of domestic companies as a percentage of GDP:

$$
\begin{aligned}
\ln \left(\Delta y_{i, t}\right) & =a+\beta_{1} \ln \left(y_{i, t-1}\right)+\beta_{2} \ln \left(G F C F_{i, t}\right)+\beta_{3} \ln \left(\text { Trade }_{i, t}\right)+ \\
& +\beta_{4} \ln \left(M k c a p_{i, t}\right)+u_{i, t}
\end{aligned}
$$

Subsequently, we have tried to determine the influence of unemployment (as a percentage of the total labour force) and of the Europe Strategy 2020 related indicator - the percentage of early leavers from education and training (as the percentage of population aged 19 to 24 years):

$$
\begin{aligned}
& \ln \left(\Delta y_{i, t}\right)=a+\beta_{1} \ln \left(y_{i, t-1}\right)+\beta_{2} \ln \left(G F C F_{i, t}\right)+\beta_{3} \ln \left(\text { Trade }_{i, t}\right)+
\end{aligned}
$$

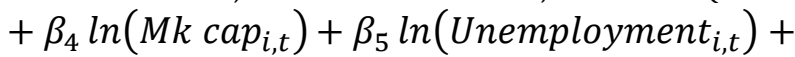

$$
\begin{aligned}
& +\beta_{6} \ln \left(\text { Early leavers }_{i, t}\right)+u_{i, t}
\end{aligned}
$$

Last, but not least, we have added an explanatory variable that is part of the Worldwide Governance Indicators and aims at the institutional quality (the rule of law):

$$
\begin{aligned}
& \ln \left(\Delta y_{i, t}\right)=a+\beta_{1} \ln \left(y_{i, t-1}\right)+\beta_{2} \ln \left(G F C F_{i, t}\right)+\beta_{3} \ln \left(\operatorname{Trade}_{i, t}\right)+
\end{aligned}
$$

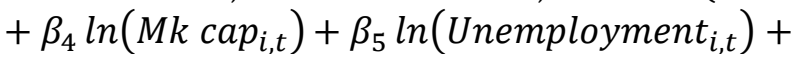

$$
\begin{aligned}
& +\beta_{6} \ln \left(\text { Early leavers }_{i, t}\right)+\beta_{7}\left(\text { Rule of law }_{i, t}\right)+u_{i, t}
\end{aligned}
$$

With the purpose to study if the income gaps between the Member States diminish over time, we have computed $\sigma$-convergence taking into consideration the coefficient of variation of the data sets. We have excluded Luxemburg from 
the analysis of $\sigma$-convergence, given the high deviation of the GDP per capita from the Community average. The coefficient of variation was determined as follows:

$$
\sigma_{t}^{2}=\left(\frac{1}{N}\right) \sum_{i=1}^{N}\left[\left(y_{i, t}\right)-\mu_{t}\right]^{2}
$$

$y_{i t}=$ GDP per capita of economy "i"

$\mu_{t}=$ the average income in the European Union

$$
\sigma_{t}=\sqrt{\sigma_{t}^{2}}, \quad C V=\frac{\sigma_{t}}{\mu_{t}}
$$

$\sigma$-convergence can be also estimated based on a simple linear regression, where the dependent variable is the coefficient of variation, and the independent variable is represented by the time period:

$$
C V\left(y_{t}\right)=\alpha_{0}+\alpha_{1} t+u_{t}
$$

$t=1, \ldots, 20$

if $\alpha_{1}<0, \sigma$-convergence hypothesis can be validated

\begin{tabular}{|c|c|c|c|}
\hline Variable & Definition & Source & Expected sign \\
\hline GDP per capita & $\begin{array}{l}\text { GDP per capita at market prices } \\
\text { (PPS per capita) }\end{array}$ & Eurostat & $\begin{array}{l}\text { The lagged } \\
\text { value - negative }\end{array}$ \\
\hline GFCF & $\begin{array}{l}\text { Gross fixed capital formation } \\
(\% \text { GDP })\end{array}$ & World Bank & Positive \\
\hline Trade & $\begin{array}{l}\text { Sum of exports and imports } \\
(\% \text { of GDP) }\end{array}$ & World Bank & Positive \\
\hline Market capitalisation & $\begin{array}{l}\text { Market capitalisation of listed } \\
\text { domestic companies (\% of GDP) }\end{array}$ & World Bank & Positive \\
\hline Unemployment & $\begin{array}{l}\text { Unemployment, total (\% of total } \\
\text { labour force) }\end{array}$ & World Bank & Negative \\
\hline Early leavers & $\begin{array}{l}\text { Early leavers from education and } \\
\text { training ( } \% \text { of population aged } 19 \\
\text { to } 24 \text { years) }\end{array}$ & Eurostat & Negative \\
\hline Rule of law & $\begin{array}{l}\text { Rule of law indicator - part of the } \\
\text { Worldwide Governance Indicators }\end{array}$ & World Bank & Positive \\
\hline
\end{tabular}

The variables, sources and the expected influence are presented in Table 1:

\section{Tab. 1 Variables, definitions and sources}

Source: Author's presentation. 


\section{Results and Discussion}

\subsection{Absolute $\beta$-convergence}

Figure 1 illustrates the results of absolute $\beta$-convergence for the European Union. The negative slope of the trend line confirms the assumptions of the neoclassical growth model, which implies that the initially poorer economies experienced higher growth rates compared to the advanced economies. At the same time, the results of $\beta$-convergence suggest a polarisation between the group of New Member States on the one hand and the Old Members on the other hand. Consequently, the CEE countries are located at the top of the graph, experiencing average growth rates above the Community average during 2000 and 2019 . According to the calculations, the highest growth rates of GDP per capita were registered by Romania (7.3\%) and the Baltic States - Lithuania (6.3\%), Estonia $(5.8 \%)$ and Latvia (5.7\%). Similarly, Bulgaria recorded a high convergence rate, reaching 5.4\%, while Hungary, Slovakia and Poland experienced average increases that ranged between $4 \%$ and $5 \%$. All the eleven countries included in the CEE group, except for Slovenia, experienced on average growth rates that exceeded 3.5\%. In the group of the Old Member States, the growth rates were lower compared to the CEE countries, ranging between $1.1 \%$ in Italy and $4.1 \%$ in Ireland. It is noteworthy that Ireland stands out with higher values compared to the other Member States, marking an exception to the neoclassical growth model. On average, the growth rate recorded by the Old Member States was $2 \%$.

Table 2 highlights the results of absolute $\beta$-convergence computed based on crosssectional data for the European Union and two subgroups of countries - the New and Old Member States. The coefficient of determination is 0.70, suggesting that growth rates at the Community level are explained in a high proportion by the initial level of GDP per capita. The negative sign of $\alpha_{1}$ coefficient, which corresponds to the initial income of the Member States, provides evidence in favour of the neoclassical growth model, confirming the negative relationship between the dependent and the independent variables. Convergence rate at the Community level, computed based on equation 2 was on average $2.5 \%$ between 2000 and 2019. Based on the estimated convergence rate, it would take more than 28 years for the European Union to reach half of the transition period towards the equilibrium state. 
Holobiuc, A.M.: Real convergence in the European Union. Bridging the gap between the New and Old Member States.

Fig. 1 Absolute $\beta$-convergence in the European Union between 2000 and 2019

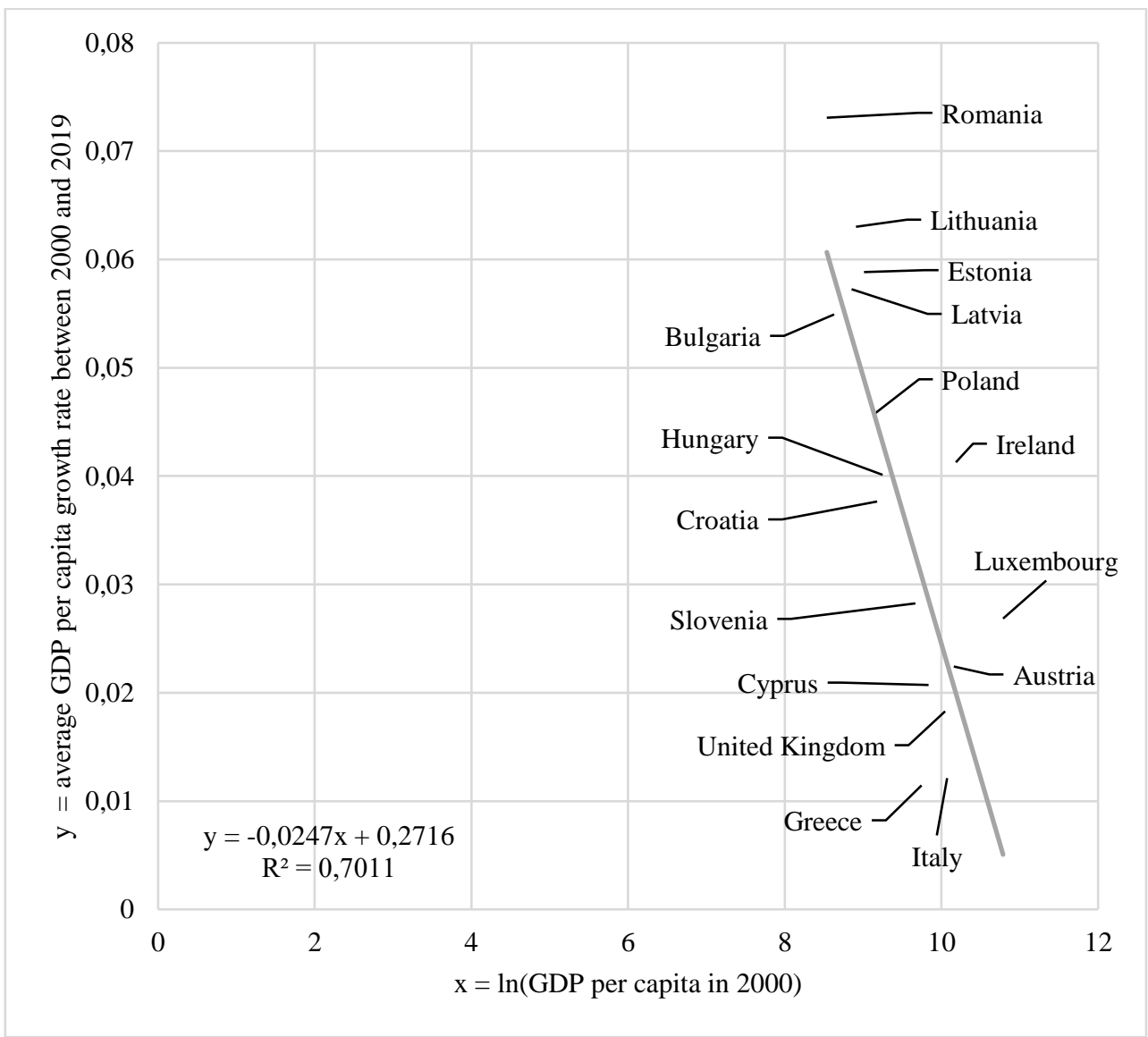

Source: Authorial computation.

Although the analysis at the aggregate level provided us with robust evidence in favour of income convergence, the assessment of the convergence/divergence patterns within the two subgroups led us to contradictory results. On the one hand, the empirical analysis indicates a strong trend of convergence at the level of the CEE countries, the catching-up speed being above the Community average and reaching about 3.6\%. The value of the coefficient of determination shows that the change in GDP is explained in a high proportion, of $82 \%$, by the initial level of income. Consequently, the New Member States would need about 19 years to reach halfway towards the equilibrium state. On the other hand, for the Old Member States, we could not identify - based on the regression 
equation -evidence in favour of the $\beta$-convergence hypothesis. In contrast, the sign of the $\alpha_{1}$ coefficient is positive, suggesting divergent trends. The value of the coefficient of determination is low, confirming that there is no relationship between the two variables. Unlike the European Union and the New Member States, where the estimated coefficients are representative at $1 \%$, in the case of the Old Members they are not statistically significant. This result might be explained by the divergent trends in the Old Members States subgroup. On the one hand, the developed economies, mainly Luxembourg and Ireland, have experienced in 2000 higher GDP per capita growth rates relative to the Community average. On the other hand, initially poorer Members, such as Greece, recorded modest growth rates, the convergence trajectory being negatively influenced by the crises that affected the European Union and the Eurozone. This evolution may call into question the neoclassical growth model assumptions, bringing evidence in favour of the endogenous theories.

\section{Tab. 2 Absolute $\beta$-convergence in the European Union, New and Old Member States}

\begin{tabular}{lccc}
\hline $\begin{array}{l}\text { Dependent Variable: Average GDP per capita growth rate between 2000-2019 } \\
\text { Method: Ordinary Least Squares }\end{array}$ & \multicolumn{3}{l}{} \\
\hline Observations & 28 & 11 & 15 \\
Dimension & European Union & New Member States & Old Member States \\
$\boldsymbol{\alpha}$ & $0.2720^{*}$ & $0.3686^{*}$ & -0.0914 \\
GDP per capita in $\mathbf{2 0 0 0}$ & $(0.0318)$ & $(0.0500)$ & $(0.0706)$ \\
$(\boldsymbol{\alpha})$ & $-0.0247^{*}$ & $-0.0352^{*}$ & 0.0111 \\
R-squared & $(0.0032)$ & $(-0.0055)$ & $(0.0069)$ \\
Adjusted R-squared & 0.6865 & 0.8197 & 0.1642 \\
$\boldsymbol{\beta}$ (convergence speed) & 0.6745 & 0.7997 & 0.0999 \\
t* & 0.0250 & -0.0358 & N/A \\
\hline
\end{tabular}

Source: Authorial computation. Note: *p-value $<1 \%$; **p-value $<5 \%$; **p-value $<10 \%$; standard errors in parentheses.

\subsection{Conditional $\beta$-convergence}

The absolute framework is complemented by the analysis of the conditional $\beta$ convergence. Based on panel regressions, we have estimated four equations, taking into consideration the influence of economic, social, and governancerelated variables. The conditional convergence analysis excludes Luxembourg, Cyprus and Malta, given the large offshore activities that might have biased the results. Table 3 presents the results obtained by using the generalised least squares method, which takes into consideration both heteroscedasticity and serial correlation between errors. The inverse relationship between the annual GDP growth rates and the lagged value of GDP per capita confirms the conditional convergence hypothesis. By using this estimation method, the values of the coefficients related to the lagged value of GDP per capita are close to those 
Holobiuc, A.M.: Real convergence in the European Union. Bridging the gap between the New and Old Member States.

obtained by studying the absolute convergence based on cross-sectional data. However, the values of the coefficients are higher as more explanatory variables are included in the model. Consequently, the results confirm the importance of economic, social, and governance framework variables on income convergence. Unlike the results obtained in the case of absolute convergence, where the convergence rate was around $2 \%$, by including in the model also economic variables, the value subsequently ranges between $3.8 \%$ and $4.9 \%$. With further expansion of the model through adding the unemployment rate and the percentage of early leavers from education, the coefficient for the variable GDP per capita has reached the value of $5.5 \%$. At the same time, by adding the indicator referring to the rule of law, the value has reached $6.5 \%$.

\section{Tab. 3 Conditional $\beta$-convergence in the European Union}

\begin{tabular}{|c|c|c|c|c|}
\hline \multicolumn{5}{|c|}{$\begin{array}{l}\text { Dependent variable: Annual GDP per capita growth rate } \\
\text { Method: Generalised Least Squares }\end{array}$} \\
\hline Equation & 1 & 2 & 3 & 4 \\
\hline $\begin{array}{l}\text { Total panel observations/ } \\
\text { Variable }\end{array}$ & 475 & 310 & 306 & 280 \\
\hline$a$ & $\begin{array}{l}0.2377^{*} \\
(0.0520)\end{array}$ & $\begin{array}{l}0.3019 * \\
(0.0662)\end{array}$ & $\begin{array}{l}0.4501^{*} \\
(0.0866)\end{array}$ & $\begin{array}{l}0.5124 * \\
(0.1507)\end{array}$ \\
\hline GDP per capita (-1) & $\begin{array}{l}-0.0378 * \\
(0.0036)\end{array}$ & $\begin{array}{r}-0.0493 * \\
(0.0062)\end{array}$ & $\begin{array}{l}-0.0552 * \\
(0.0073)\end{array}$ & $\begin{array}{l}-0.0648 * \\
(0.0148)\end{array}$ \\
\hline GFCF & $\begin{array}{c}0.0374 * * \\
(0.0166)\end{array}$ & $\begin{array}{c}0.0335^{* *} \\
(0.0138)\end{array}$ & $\begin{array}{c}0.0230 * * \\
(0.0147)\end{array}$ & $\begin{array}{c}0.0251 * * \\
(0.0154)\end{array}$ \\
\hline Trade & $\begin{array}{r}0.0127 * * \\
(0.0057)\end{array}$ & $\begin{array}{l}0.0185^{*} \\
(0.0045)\end{array}$ & $\begin{array}{l}0.0128 * \\
(0.0042)\end{array}$ & $\begin{array}{l}0.0155^{*} \\
(0.0049)\end{array}$ \\
\hline Market capitalisation & & $\begin{array}{l}0.0100 * \\
(0.0030)\end{array}$ & $\begin{array}{l}0.0111 * \\
(0.0028)\end{array}$ & $\begin{array}{l}0.0119 * \\
(0.0031)\end{array}$ \\
\hline Unemployment & & & $\begin{array}{c}-0.0111^{* *} \\
(0.0046)\end{array}$ & $\begin{array}{c}-0.0088 * * \\
(0.0043)\end{array}$ \\
\hline Early leavers & & & $\begin{array}{c}-0.0053 * * * \\
(0.0030)\end{array}$ & $\begin{array}{c}-0.0063 * * \\
(0.0032)\end{array}$ \\
\hline Rule of law & & & & $\begin{array}{l}0.0079 * \\
(0.0089)\end{array}$ \\
\hline Prob (F-statistic) & 0.0000 & 0.0000 & 0.0000 & 0.0000 \\
\hline R-squared & 0.2193 & 0.2998 & 0.2559 & 0.2681 \\
\hline Adjusted R-squared & 0.2143 & 0.2382 & 0.2410 & 0.2492 \\
\hline Durbin Watson & 1.7421 & 1.9595 & 1.7662 & 1.8051 \\
\hline$\beta$ (convergence speed) & -0.0385 & -0.0505 & -0.0567 & -0.0669 \\
\hline$t^{*}$ & 18 & 13.7 & 12.2 & 10.3 \\
\hline
\end{tabular}

Source: Authorial computation.

Note: $*$ p-value $<1 \% ; * *$ p-value $<5 \%$; $* *$ p-value $<10 \%$; robust standard errors in parentheses. 


\section{Tab. 4a Conditional $\beta$-convergence in the New and Old Member States}

\begin{tabular}{|c|c|c|c|c|}
\hline \multicolumn{5}{|c|}{$\begin{array}{l}\text { Dependent variable: Annual GDP per capita growth rate } \\
\text { Method: Generalised Least Squares }\end{array}$} \\
\hline Equation & \multicolumn{2}{|c|}{1} & \multicolumn{2}{|c|}{2} \\
\hline Group & NMS & OMS & NMS & OMS \\
\hline Total panel observations/ Variable & 209 & 266 & 118 & 192 \\
\hline$a$ & $\begin{array}{l}0.3994^{*} \\
(0.0339)\end{array}$ & $\begin{array}{l}0.2448^{*} \\
(0.0824)\end{array}$ & $\begin{array}{l}0.3363 * \\
(0.0575)\end{array}$ & $\begin{array}{r}0.2478 * * \\
(0.1054)\end{array}$ \\
\hline GDP per capita (-1) & $\begin{array}{c}-0.0753 * \\
(0.0042)\end{array}$ & $\begin{array}{c}-0.0405 * \\
(0.0086)\end{array}$ & $\begin{array}{l}-0.0516 * \\
(0.0083)\end{array}$ & $\begin{array}{c}-0.0427 * \\
(0.0120)\end{array}$ \\
\hline Gross Fixed Capital Formation & $\begin{array}{l}0.0657 * \\
(0.0064)\end{array}$ & $\begin{array}{l}0.0300 * \\
(0.0052)\end{array}$ & $\begin{array}{l}0.0479 * \\
(0.0136)\end{array}$ & $\begin{array}{c}0.0213 * * \\
(0.0087)\end{array}$ \\
\hline Trade & $\begin{array}{l}0.0357 * \\
(0.0059)\end{array}$ & $\begin{array}{l}0.0225 * \\
(0.0030)\end{array}$ & $\begin{array}{c}0.0115 \\
(0.0107)\end{array}$ & $\begin{array}{l}0.0223 * \\
(0.0044)\end{array}$ \\
\hline Market capitalisation & & & $\begin{array}{c}0.0011 \\
(0.0037)\end{array}$ & $\begin{array}{c}0.0118 \\
(0.0022)\end{array}$ \\
\hline $\begin{array}{l}\text { Unemployment } \\
\text { Early leavers } \\
\text { Rule of law }\end{array}$ & & & & \\
\hline Prob (F-statistic) & 0.0000 & 0.0000 & 0.0000 & 0.0000 \\
\hline R-squared & 0.6998 & 0.2418 & 0.3008 & 0.1390 \\
\hline Adjusted R-squared & 0.6954 & 0.2331 & 0.2761 & 0.1206 \\
\hline Durbin Watson & 1.8870 & 1.9184 & 1.9170 & 1.8302 \\
\hline$\beta$ (convergence speed) & -0.0782 & -0.0413 & -0.0529 & -0.0436 \\
\hline$t^{*}$ & 8.8 & 16.8 & 13 & 15.9 \\
\hline
\end{tabular}

Source: Authorial computation.

Note: $*$ p-value $<1 \% ; * *$ p-value $<5 \%$; ***p-value $<10 \%$; robust standard errors in parentheses. NMS - New Member States; OMS - Old Member States

The estimated model confirms the beneficial influence of investment, trade in goods and services, and developed financial markets on convergence. Moreover, a stable governance framework, especially in the field of the rule of law, was an important catalyser of economic growth. According to the initial expectations, a high rate of the unemployment rate and early leavers from education and training had a negative effect on growth rates, as reflected in equations 3 and 4 . The estimated model shows that the role of economic variables outweighs that of the social factors, the values of the coefficients related to the gross fixed capital formation and trade being high and statistically significant in the case of all four equations. The extended model explains in a proportion of $26 \%$ the variation of economic growth rates at the Community level between 2000 and 2019. 
Holobiuc, A.M.: Real convergence in the European Union. Bridging the gap between the New and Old Member States.

Tab. 4b Conditional $\beta$-convergence in the New and Old Member States

\begin{tabular}{|c|c|c|c|c|}
\hline \multicolumn{5}{|c|}{$\begin{array}{l}\text { Dependent variable: Annual GDP per capita growth rate } \\
\text { Method: Generalised Least Squares }\end{array}$} \\
\hline Equation & \multicolumn{2}{|c|}{3} & \multicolumn{2}{|c|}{4} \\
\hline Group & NMS & OMS & NMS & OMS \\
\hline Total panel observations/ Variable & 115 & 191 & 106 & 174 \\
\hline \multirow[t]{2}{*}{$a$} & $0.8853^{*}$ & $0.5922 *$ & $1.0924 *$ & $0.7871^{*}$ \\
\hline & $(0.1704)$ & $(0.1197)$ & $(0.2374)$ & $(0.1422)$ \\
\hline \multirow[t]{2}{*}{ GDP per capita $(-1)$} & $-0.1000 *$ & $-0.0784 *$ & $-0.1243 *$ & $-0.0987 *$ \\
\hline & $(0.0194)$ & $(0.0131)$ & $(0.0255)$ & $(0.0156)$ \\
\hline \multirow[t]{2}{*}{ Gross Fixed Capital Formation } & 0.0206 & $0.0435 *$ & 0.0213 & $0.0467 *$ \\
\hline & $(0.0160)$ & $(0.0088)$ & $(0.0183)$ & $(0.0096)$ \\
\hline \multirow[t]{2}{*}{ Trade } & $0.0324 * *$ & $0.0227 *$ & $0.0424 *$ & $0.0258 *$ \\
\hline & $(0.0141)$ & $(0.0038)$ & $(0.0138)$ & $(0.0042)$ \\
\hline \multirow[t]{2}{*}{ Market capitalisation } & 0.0004 & $0.0156^{*}$ & 0.0033 & $0.0159 *$ \\
\hline & $(0.0033)$ & $(0.0019)$ & $(0.0067)$ & $(0.0022)$ \\
\hline \multirow[t]{2}{*}{ Unemployment } & $-0.0229 *$ & - & $-0.0243 *$ & $-0.0083 *$ \\
\hline & $(0.0068)$ & $\begin{array}{c}0.0048 * * * \\
(0.0025)\end{array}$ & $(0.0092)$ & $(0.0030)$ \\
\hline \multirow[t]{2}{*}{ Early leavers } & $-0.0226^{*}$ & $-0.0205^{*}$ & $-0.0318^{*}$ & $-0.0239 *$ \\
\hline & $(0.0072)$ & $(0.0036)$ & $(0.0091)$ & $(0.0043)$ \\
\hline \multirow[t]{2}{*}{ Rule of law } & & & 0.0012 & 0.0024 \\
\hline & & & $(0.0078)$ & $(0.0035)$ \\
\hline Prob (F-statistic) & 0.0000 & 0.0000 & 0.0000 & 0.0000 \\
\hline R-squared & 0.3355 & 0.2559 & 0.3369 & 0.3149 \\
\hline Adjusted R-squared & 0.2986 & 0.2410 & 0.2886 & 0.2850 \\
\hline Durbin Watson & 1.8929 & 1.7662 & 1.9547 & 2.0047 \\
\hline$\beta$ (convergence speed) & -0.1053 & -0.0816 & -0.1327 & -0.1039 \\
\hline$t *$ & 6.6 & 8.5 & 5.2 & 6.7 \\
\hline
\end{tabular}

Source: Authorial computation.

Note: *p-value < 1\%; **p-value < 5\%; ***p-value < 10\%; robust standard errors in parentheses. NMS - New Member States; OMS - Old Member States

\section{3. $\sigma$-convergence}

In order to study if $\beta$-convergence was accompanied by a reduction of income gaps between countries, we have studied $\sigma$-convergence for the European Union, the Old and New Member States. In this respect, Figure 2 illustrates the evolution of the coefficient of variation during the timespan 2000-2019. Luxembourg was excluded from the analysis, given the large deviation from the Community average GDP per capita. Income disparities decreased with $32 \%$ during the period 
considered in the European Union, from 0.43 to 0.3 , so $\beta$-convergence was accompanied by $\sigma$-convergence. The analysis of the two subgroups indicates a reduction of income gaps among the New Member States relative to the Community average, the coefficient of variation decreasing by more than $50 \%$ over the 20 years. The performance of the CEE economies was not significantly obstructed by the economic and financial crisis, with the value of the coefficient of variation slightly increasing from 0.33 (2008) to 0.34 (2009), and subsequently returning to a downward trajectory. Although the Old Member States exhibited a declining trend compared to the European Union's average between 2000 and 2009, the economic and sovereign debt crises had a negative influence on the income per capita distribution, eroding the progress achieved at the beginning of the millennium.

\section{Fig. $2 \sigma$-convergence in the European Union between 2000 and 2019}

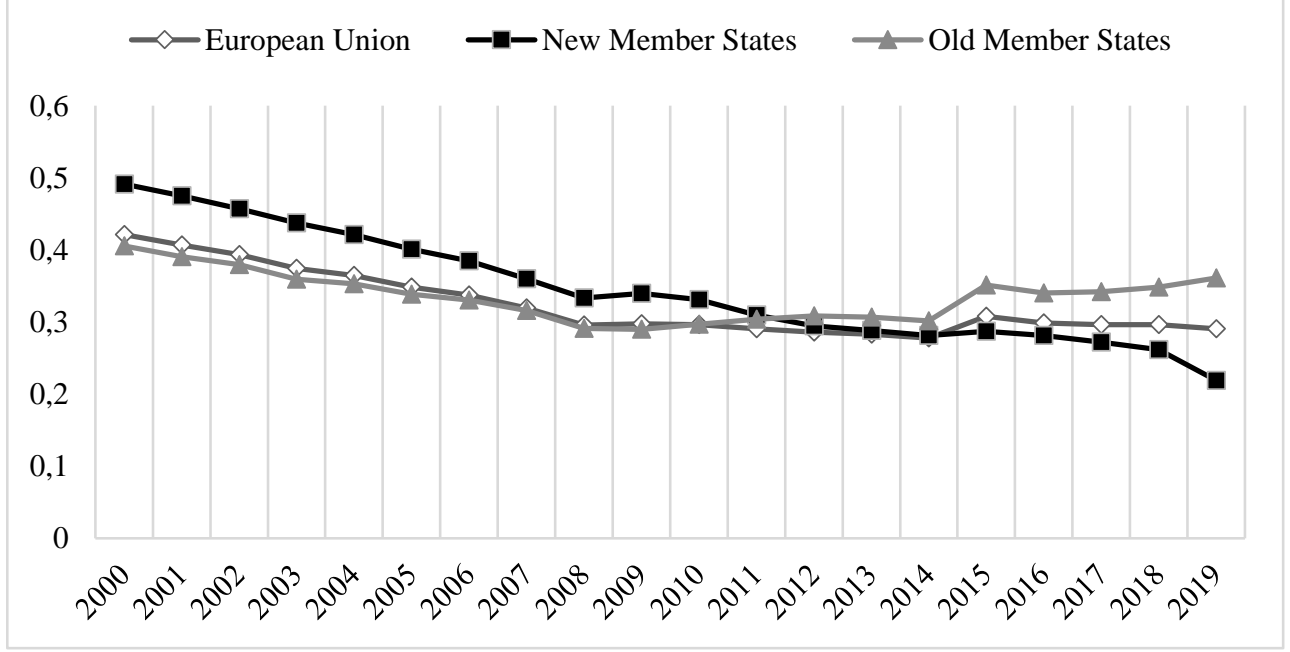

Source: Authorial computation.

The conclusions derived from the graphical representations are also confirmed by the regression analysis, where the dependent variable is the coefficient of variation of the data sets and the independent variable is the time factor (equation 10). As the coefficient $\alpha_{1}$ is negative and statistically significant ( $\mathrm{p}$-value $<1 \%$ ), we may conclude that income divergences decreased in the European Union. The analysis conducted at the subgroup level indicates a reduction of income gaps during the analysed period for the New Member States. The coefficient of determination is 0.95 in this case, suggesting a strong relationship between the variables. In contrast, in the estimation for the Old Members group, the coefficient of determination has very low values. Consequently, we have found no statistically significant evidence in favour of $\sigma$ - 
Holobiuc, A.M.: Real convergence in the European Union. Bridging the gap between the New and Old Member States.

convergence for this subgroup. Overall, we may conclude that the positive trend identified in the European Union was mainly determined by the progress achieved by the New Members.

\section{Tab. 5 o-convergence in the European Union}

\begin{tabular}{|c|c|c|c|}
\hline \multicolumn{4}{|c|}{$\begin{array}{l}\text { Dependent Variable: Coefficient of variation } \\
\text { Method: Ordinary Least Squares }\end{array}$} \\
\hline Observations & 20 & 20 & 20 \\
\hline Variable & European Union & New Member States & Old Member States \\
\hline \multirow{3}{*}{$\boldsymbol{\alpha}_{0}$} & $0.3921 *$ & $0.4823 *$ & $0.3583^{*}$ \\
\hline & $(0.1111)$ & $(0.0080)$ & $(0.0148)$ \\
\hline & $-0.0064 *$ & $-0.0129 *$ & $-0.0021 * * *$ \\
\hline Time & $(0.0009)$ & $(0.0006)$ & $(0.0012)$ \\
\hline R-squared & 0.7311 & 0.9541 & 0.1441 \\
\hline Adjusted R-squared & 0.7162 & 0.9516 & 0.0966 \\
\hline$\sigma$-convergence & yes & yes & $\begin{array}{l}\text { Not statistically } \\
\text { significant }\end{array}$ \\
\hline
\end{tabular}

Source: Authorial computation. Note: *p-value < 1\%; **p-value < 5\%; ***p-value < 10\%; standard errors in parentheses.

\section{Conclusions}

During its almost seven decades of existence, the European Union has succeeded to promote peace and stability within the European continent, transforming former foes in friends, turmoil in peace and poverty in prosperity. This paper aimed to study the convergence process in the European Union by taking into consideration the evolution of income per capita between 2000 and 2019 . In this respect, our methodology was based on the absolute and conditional $\beta$ - and $\sigma$-convergence. The analysis of $\beta$-convergence confirmed the neoclassical growth model assumptions, as the initially poorer members from CEE have experienced higher GDP growth rates than the developed Western economies. We have found evidence in favour of the "iron law" of convergence of 2\% (Barro, 2012), the catching-up speed identified for the European Union being on average $2.5 \%$. The comparison of the absolute $\beta$-convergence for the two subgroups of countries (the New and Old Member States) provided some interesting evidence regarding the convergence/divergence patterns. On the one hand, the empirical analysis suggested that the New Member States made important progress in terms of catching-up, the convergence speed reaching on average $3.6 \%$ between 2000 and 2019. On the other hand, no statistically significant relationship between the variables was identified for the cluster of Old Members.

The absolute convergence was complemented by the analysis of the conditional framework. In order to control for the differences between economies, the empirical model included variables related to investment, trade, financial 
and labour market, education, and governance framework. The negative relationship between the lagged value of GDP per capita and the annual GDP growth rates confirmed the conditional $\beta$-convergence hypothesis for both the European Union and the two subgroups of countries. Moreover, the value of the coefficients has increased once the equations were expanded, emphasising the importance of macroeconomic and social variables in promoting economic growth. Our study has a number of policy implications. First of all, it emphasises the role of investment in enhancing economic growth both at the aggregate and subgroup level. Moreover, as the trade in goods and services proved to be an important determinant, the European decision-makers should promote the exchanges with third countries and continue the efforts in the field of liberalisation and reduction of non-tariff barriers. Our study also suggests that a well-developed financial market contributed to the convergence process between 2000 and 2019, mainly in the cluster of Old Member States. As the influence in the New Member subgroup was significantly lower, our study suggests that the CEE group still has to take steps to strengthen the domestic financial markets. In the field of labour market indicators, the empirical analysis confirms that an increase in the level of unemployment rate hampers the catching-up process both at the aggregate and subgroup level. Moreover, a high percentage of early leavers from education and training negatively influence the GDP per capita growth rates. Consequently, the efforts to accomplish the Strategy Europe 2020 objectives in the field of education enhanced the prosperity of the European citizens. Last but not the least, a stable governance framework, in terms of the rule of law, proved to have a positive influence on economic growth. Consequently, our study suggests that apart from macroeconomic determinants, social and governance-related variables influenced the growth path in the European Union. In order to evaluate if $\beta$-convergence was accompanied by a reduction of income gaps at the Community level and within the two subgroups, we have used $\sigma$-convergence. Our analysis confirmed that the income disparities diminished within the European Union and the cluster of New Member States. However, although the Old Member States were on an upward trajectory at the beginning of the $21^{\text {st }}$ century, the emergence of the economic and financial crisis determined an increase of income disparities.

Overall, our study suggests that the objective of real convergence has not been accomplished so far at the Community level. However, the New Members from CEE have made important steps in terms of catching-up, reducing the income differentials compared to the European Union's average. In contrast, the Old Members group experienced modest economic growth during the timespan 20002019 and even an increase of divergences, as reflected by $\sigma$-convergence. The main limitation of the study derives from the short period taken into consideration. However, we considered that the crisis that took place at the end 
Holobiuc, A.M.: Real convergence in the European Union. Bridging the gap between the New and Old Member States.

of the last century might have distorted the results, mainly for the group of New Members. Other shortcomings of the study derive from the limited set of variables taken into consideration within the study of the conditional convergence model. Consequently, the study could be expanded by taken into consideration the influence of other economic, social and governance-related indicators. 


\section{References}

Alcidi, C., Núñez Ferrer, J., Di Salvo, M., Pilati, M., Musmeci, R., 2018. Income Convergence in the EU: A Tale of Two Speeds. CEPS Commentary. Centre for European Policy Studies.

Barro, R. J., Sala-i-Martin, X., 1990. Economic Growth and Convergence across The United States. NBER Working Paper no. 3419.

Barro, R. J. and Sala-i-Martin, X., 1992. Convergence. Journal of Political Economy, 100(2), 223-251.

Barro, R. J., 2012. Convergence and Modernization Revisited. NBER Working Paper no. 18295, National Bureau of Economic Research.

Dobrinsky, R., Havlik, P., 2014. Economic Convergence and Structural Change: the Role of Transition and EU Accession. Wiiw Research Report No. 395. The Vienna Institute for International Economic Studies.

Dobrinsky, R., 2013. What is Happening to Growth in Europe? Wiiw Research Report No. 385. The Vienna Institute for International Economic Studies.

Eurostat. Database. Available from: <ec.europa.eu/eurostat/data/database>. [17 September 2021].

Lucas, R., 1988. On the mechanics of economic development. Journal of Monetary Economics, 22(1), 3-42.

Ramsey, F. P., 1928. A Mathematical Theory of Saving. Economic Journal, London, 38(152), 543-559.

Rapacki, R., Próchniak, M., 2009. The EU enlargement and economic growth in the CEE new member countries. European Economy. Economic Paper 367. Brussels: European Commission.

Rapacki, R., Prochniak, M., 2019. EU membership and economic growth: Empirical evidence for the CEE countries. European Journal of Comparative Economics, 16(1), 3-40.

Romer, P. M., 1989. Human Capital and Growth: Theory and Evidence. NBER Working Paper No. 3173. National Bureau of Economic Research.

Solow, R. M., 1956. A Contribution to the Theory of Economic Growth. The Quarterly Journal of Economics, 70(1), 65-94.

Stanišić, N., 2012. The effects of the economic crisis on income convergence in the European Union. Acta Oeconomica, 62(2), 161-182.

Stoica, O., Roman, A., Diaconaşu, D. E., 2019. Real Convergence and European Integration with Focus on the New Member States. Scientific Annals of Economics and Business, 66(SI2), 215-228. 
Holobiuc, A.M.: Real convergence in the European Union. Bridging the gap between the New and Old Member States.

Swan, T. W., 1956. Economic growth and capital accumulation. The Economic Record. 32(2), 334-361.

Vojinović, B., Acharya, S., Próchniak, M., 2009. Convergence Analysis Among the Ten European Transition Economies. Hitotsubashi Journal of Economics, 50(2), 17-35.

World Bank. Data. Available from: <data.worldbank.org/>. [17 September 2021]. 